\title{
THE IMPLEMENTATION AND HUMAN RIGHT LAW OF POLICY ABOUT STUNTING PREVENTIONIN COVID -19 ERA IN KENDARI
}

\author{
Yunita Amraeni ${ }^{1}$, Toto Surianto ${ }^{2}$, M. Nirwan ${ }^{3}$ \\ 1,2,3 Department of Public Health, Faculty of Sciences, Universitas Mandala Waluya, \\ in Kendari, Southeast Sulawesi Province, Indonesia.
}

Corresponding Author : Yunita Amraeni

Email : zahra.kahfi@gmail.com.

\begin{abstract}
Background.Stunting during the covid period requires policies of handling and prevention in accordance with law and human rights. Therefore, this study aims to determine the prevention strategies and human rights law related stunting to develop the health policy.

Method.A qualitative method through in-depth interviews was conducted on 6 informants from the city health office and health centre for strategy and literature study related to human rights and stunting policy law.

Results. The results show that there are several strategies that can be prioritized to overcome stunting in the Covid era, such as promotion and support of breastfeeding, Campaign for balanced nutrition and Clean and Healthy Living Behavior (PHBS), Education and counseling using the media, including Short Letter (SMS), or WhatsApp group, Priority services for children under five, through health services and home visits, provision of additional food for malnourished toddlers and pregnant women with chronic energy deficiency, and provision of nutritional supplementation.

Conclusion. It is necessary to modify the policy to improve the strategies at the regional level so that stunting can be solved in the pandemic and providing child protection people with stunting an obligation and the joint responsibility of the state, community, family and parents covering juridical protection, economic, social and cultural. Therefore, in fulfilling basic rights child, then the responsibility is carried out holistically by collaborating with the stakeholder.
\end{abstract}

Keywords : Stunting, Human Right, Policy, Kendari 


\section{INTRODUCTION}

Another problem that needs to be faced by Indonesia besides the COVID-19 pandemic is malnutrition which can lead to stunting. Stunting important issue to be resolved, as it relates to health, even the death of the child (3). Inadequate intake can affect weight loss, weight loss (weight gain does not match the curve), the difficulty of appetite, and malnutrition. Growth and development are not in accordance with age can also be a sign that the immune system of children has decreased which makes it more vulnerable to infection, including pathogens such as viruses $(19,21)$.

Toddlers Nutritional Status Survey Indonesia (SSGBI) showed a decline in the numbers of stunting from 30.8 percent in 2018 to 27.67 percent in 20197. Although this figure decreased stunting, the figure is still relatively high, given the WHO target the stunting figures should not be more than 20 percent. This condition was exacerbated by the Covid-19 pandemic attack which led to an increase in poverty in the community. Problems stunting or conditions of growth failure in children under five that have bodies that are too short compared to the age, remains a major challenge facing this nation6. Based on the Global Nutrition Report 2018, Indonesia Stunting prevalence of 132 countries ranked 108, while in Southeast Asia, the prevalence of stunting Indonesia ranks second to that of Cambodia (13).

Based on data from the Health Research (Riskesdas) Ministry of Health, the number of national stunting decreased from $37.2 \%$ in 2013 to $30.8 \%$ in 2018. Based on Nutritional Status Survey Toddler Indonesia (SSGBI) in 2019 decreased to $27.7 \%$ (3). The decline in stunting has been declared a national priority programs. Currently, the Government continues to move to organize implementation tools to accelerate stunting prevention and formulate the National Strategy (Stranas) for the Acceleration of Stunting Prevention for 2018-202421. The Government through the National Medium
Term Development Plan (RPJMN) 20202024 has also set a target rate of national stunting dropped to $14 \%(6,10,15)$.

Overburdened health facilities, disrupted food supply chains, and lost income due to COVID-19 can cause a sharp increase in the number of malnourished children in Indonesia. Even before COVID-19, Indonesia was already facing high nutritional problems (17). Currently, more than two million children suffer from malnutrition and more than seven million children under the age of 5 are stunted (18).Recent UNICEF estimates suggest that if there is no timely action, the number of children who are severely deprived or malnourished under 5 years of age could increase globally by about 15 percent this year due to COVID-19 (13). This means that there is an increased risk of wasting, a condition characterized by low body weight when compared to height, besides that in Indonesia, many families have lost household income and are less able to buy healthy and nutritious food for their children. At the same time, there is ample evidence to suggest that children who are losing are more likely to be stunted, or have a lower height for their age, and may result in more children being stunted in that country (21). Children who experience stunting and miscarriage are prone to longterm developmental disorders11. Posyandu is actively trying to prevent stunting, conduct socialization and education, and implement programs. However, during the COVID-19 pandemic, this activity was hampered $(15,21)$.

The number is certainly very worrying, given that the most valuable resource for a country is a human resources (HR) quality. The future of our nation is in the hands of 79.55 million children in Indonesia (4). So, it is important in fulfilling children's rights to the quality of resources in the future. Some of the factors that cause stunting among others due to poor parenting, health services are limited, families lacking access to nutritious food, lack of access to clean water and sanitation nutrition must be optimized by 


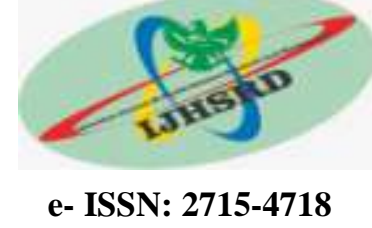

all parties to ensure the fulfillment of balanced nutrition for children. Therefore,This study aims to explore stunting prevention policies based on existing policy strategies and laws.

\section{Method}

This study uses a qualitative study with Indepth Interview to explore the policy strategy of prevention of stunting during pandemics and literature studies for legal alignment stunting policies that have been implemented.One Heads of city agencies and Fivehealth centers in the city kendari as policy makers. Then the qualitative data transcript is made according to the theme and coded to get the keywords.

\section{Result}

\section{Strategy of Stunting Prevention in Covid era}

Following are some statements from informants regarding policies and strategies for preventing stunting during a pandemic "In the event of this pandemic, it is feared that the national program to reduce stunting and tackle malnutrition cannot be carried out properly" (HA).

"The issue of fund refocusing programs that can reduce funds for the implementation of the national stunting program in the regions" (HC 3).

"The importance of the role of macronutrients and essential amino acids from the first 2 years of life and calling on the use of digital media for stunting prevention, for example the use of digital technology to monitor the nutritional status of children at home. There is an increased risk of acute and chronic nutritional problems caused by reduced access and purchasing power of people to nutritious food due to the Covid-19 pandemic" (HA).

"Due to covid, community visits have been minimized to health service facilities (fasyankes) and prioritize them for urgent and emergency ones. We balance it with service modification plans such as home visits for at-risk targets, virtual counseling, community education, and communication through groups on social media. Monitoring of the nutritional status of children under five at Posyandu is now on hold" (HC 1).

"However, the community is expected to continue to provide breast milk for babies, food according to the guidelines for balanced nutrition for children, wash hands and PHBS, to carry out physical activities" (HC 5).

"The public is urged to immediately contact cadres or health care facilities if the child has decreased appetite, weight loss, or other health problems.This effort cannot be run by families alone, but also requires collaboration between parties such as schools, to provide supervisory education among adolescents" (HC 2).

"One of the efforts is socialization, education and online monitoring through social media. Assistance is provided so that pregnant women and their partners can get information related to good nutritional intake during pregnancy, such as a healthy balanced menu, intake of iron, folic acid and iodine" (HC 4)

\section{Stunting prevention legal policies}

Malnutrition (stunting) is not new because since the first government has taken 
policy through the program tackling the problem of stunting in Indonesia (5). In addition, the government has protected rights children like the right to life, the right to health, the right to grow and develop like humans generally as stipulated in of the constitution Article (28) B paragraph (2) of the Law Republic of Indonesia (UUD NRI) In 1945 it was emphasized that: "Every child entitled to survival, growth and developing and entitled to protection from violence and discrimination ", in addition, in various laws and regulations which regulates the right to life of children such as Law Number 4 of 1979 concerningChild Welfare, Law No. 23 2002 concerning Child Protection, Law Number 36 of 2009 concerning Health, it is even regulated in Law Number 39 of 1999 concerning Human Rights (2). Fact it happens that the sufferer is relatively stunted high or still below the standard $20 \%$ by WHO $(12,14)$. Stunting it should be becomes the government's concern, given the impact which is quite serious for the child and has implications on the nation's future. From this phenomenon, then the focus of the study in this study, namely protection and enforcement of human rights law humans for children with stunting $(8,9)$.

There are three forms of liability and responsibility state responsibility for protecting children which is based on human rights, firstly, Respect (obligation to respect) that is the state's obligation not to interfere in regulating citizens his country when exercising his rights. In this case, the state has an obligation to do those actions will hinder fulfillment of all the human rights of children with stunting. Secondly, Protect (obligation to protect) that is the state's obligation to act active to guarantee protection. This means that the state is obliged to take actions for prevent violations of all children's rights by party. Thirdly, Fulfill (obligation to fulfill) is an obligation and responsibility state to act actively in order All citizens of that country have their rights fulfilled, including the rights of children with stunting. The state is obliged to take legislative, administrative, law, and other acts for fully realize children's human rights.

\section{Discussion}

Stunting (short) is a condition in which children under five are less long or tall than their age (19).Stunting is one of the targets of the Sustainable Development Goals (SDGs) which is included in the second sustainable development goal, namely eliminating hunger and all forms of malnutrition by 2030 and achieving food security20.The target set is to reduce the stunting rate by $40 \%$ by 2025 (13).

Based on this research, the following are ways to prevent stunting during the pandemic COVID-19 prioritized at toddler groups, pregnant women, and breastfeeding such as 1) Promotion and support of breastfeeding, 2) Campaign for balanced nutrition and Clean and Healthy Living Behavior (PHBS), 3) Education and counseling using the media, including Short Letter (SMS), or WhatsApp group 4) Priority services for children under five, through health services and home visits, 5) Provision of additional food for malnourished toddlers and pregnant women with chronic energy deficiency, 6) Provision of nutritional supplementation.

In response to COVID-19, UNICEF is working with the government to continue nutrition services for vulnerable children and families, including growth monitoring, distribution of micronutrients, support for mothers to adequately feed babies and children, and screening and care for children under five due to poor nutrition (21). The government cannot work alone, it needs synergy, commitment and good innovation with community institutions, especially local governments. The importance of convergence between programs, so that they can target the smallest community groups.The stunting reduction strategy is carried out through 5 (five) pillars, namely (1) leadership commitment and vision;(2) campaigns and behavior change;(3) convergence of central, 
regional and village programs;(4) food and nutrition security;and (5) monitoring and evaluation (17).

The importance of implementing a strategy to reduce stunting rates through education and meeting the needs of nutrition and sanitation, behavior change, especially for pregnant women and ensuring that the baby's growth remains good from the womb to after birth.Pitasari and Kirana also said that the target to reduce stunting to $14 \%$ is very difficult to achieve under normal conditions, especially in the midst of a pandemic (17).For this reason, high-level commitment is required through various policies / regulations, developing innovation, human resources, and institutions in order to expand the scope of the program."The importance of strengthening the quality of existing programs with creativity and culture-based innovation according to the potential of each region.This will accelerate the stunting reduction target in Indonesia.

The COVID-19 pandemic makes it possible for the number of stunted children (chronic malnutrition) in Indonesia to increase. So it is predicted that the target to reduce stunting of up to 14 percent is difficult to achieve, considering that Posyandu is no longer operating and health workers at Puskesmas are also not immune from the impact of COVID-19. Early detection such as routine growth monitoring in health facilities is important in preventing malnutrition in children (13). If it is not quickly detected by measuring body weight, body length and head circumference, children can suffer from chronic malnutrition and become stunted. In order for the stunting rate to fall, it is necessary to modify the policy strategy that can be implemented at the local level. It is hoped that the closure of the posyandu can be overcome by the application of a clean and healthy life for each family. Mothers are expected to continue giving breastmilk to babies, eating according to balanced nutrition guidelines for children, washing hands and PHBS, to doing physical activity. In addition, people are urged to immediately contact cadres or health facilities if the child has decreased appetite, weight loss, or other health problems. With regard to specific strategies for preventing stunting during the pandemic, the key is to provide good nutrition, routine growth and development monitoring for early detection, and a tiered referral system.

Government program policies relating to the handling of stunting as manifestation of protection of children's rights is a constitutional order for protection towards children is part of human rights human (12). Hence, child recovery from stunting is the responsibility of the state in order children can live healthy and get life worthy. Every child has the right to service good health, the right to food (intake nutrition), the right to welfare. This right is recognized in statutory regulations, namely UUD NRI 1945, Law Number 4 of 1979 concerning Child Welfare, Law Number 23 of 2002 concerning Child Protection, Law No. 362009 concerning Health, Law Number 3 of 1997 concerning Juvenile Justice, The Food Law is even regulated in Law Number 39 of 1999 concerning Human rights. Meanwhile, special rights for children stunting sufferers have not been specifically regulated in national law.

Health is a human right that must be fulfilled by the government because it is its constitutional duty, as mandated in Article (28) paragraph (1) of the NRI Constitution which reads "everyone has the right to live in physical and mental well-being, to live in, and to have a good and healthy living environment. and entitled to health services. The right to health is also explicitly regulated in Article (4) of Law of the Republic of Indonesia Number 36 of 2009 concerning Health which states that "everyone has the right to health". Because the right to health is a fundamental right that the government must strive to fulfill for citizens, especially children who are the nation's next generation, efforts to prevent stunting in children must be of particular concern. 
According to the theory of human rights, natural rights (natural rights): Human rights are rights that belong to all human beings at all times and in all places by virtue of being born as human beings) $(1,2,8)$. HAM is a right that belongs to all humans at all times and places based destiny as a human (8). In the context of Indonesian people's life that death who took the lives of the nation's children with because of the unavailability of protection and health services can be categorized as human rights violations. Violation of rights health is a violation of the constitution (14). Thus, the government's failure in maximizing prevention program policies and restoring the health of stunting children is a form of human rights violation carried out by the state, because it does not fulfill their rights constitutional child. If the child is stunted not restored, it will ruin the future children and nation even cause death. The rights violated by the state are rights healthy, the right to grow and develop, the right to welfare children, right to education, right to standard of living proper, and includes the right to life. Right to life is a non derogable right which cannot be restricted under any circumstances as a boon from God.

\section{Conclussion}

A number of health protocols urged by the government to handle the Covid-19 pandemic have the potential to have an impact on handling stress or stunting in Indonesia. For this reason, it is necessary to modify the policy strategy at the regional level so that the handling of stunting can continue amid the pandemic. In order to achieve the target of reducing the national stunting rate, which is a national priority program, it is necessary to modify the policy strategy that can be implemented at the regional level. So, we can still prevent malnutrition and save the future of Indonesian children in the midst of a pandemic.Protection and fulfillment of rights constitutional citizen must do in accordance with the conditions of citizens of the country with the fact that in Indonesian society there is a difference in ability (caused because the developing social structure tends to marginalize it) to access protection and fulfillment of the rights given by state. Providing child protection people with stunting an obligation and the joint responsibility of the state, community, family and parents covering juridical protection, economic, social and cultural. Therefore, in fulfilling basic rights child, then the responsibility is carried out holistically by collaborating with the stakeholder.

\section{Reference}

1. Al-Atok, A. Rashid. "Indonesian rule of law" (2016): 1-18. http://lab.pancasila.um.ac. id / wpcontent / uploads / 2016/05 / The State Law of Indonesia By A-Rosyid-AlAtok. Pdf

2. Asshidiqie, Jimly. Caring for and Fulfilling the Guarantee of Citizens' Constitutional Rights. Jakarta, 2010.

3. Azizah, KhadijahNur (2018). "Ministry of Health Launches Riskesdas 2018, Stunting Rate Declines!" Detik Health, November 2018. https: // health. detik.com/berita-detikhealth/d4284274/ kemenkes-launch-riskesdas2018-stunting-numbers-down.

4. Izwardi, Doddy (2019). "Policies and Strategies for Poverty Reduction in Indonesia." DYNAMICS Rural and Area 2, no. 2: 41-52.

5. Ministry of Health of the Republic of Indonesia (2018). "Stunting Reduction is the Government's Focus." Ministry of Health RI. Jakarta. http: // www. depkes.go.id/article/view/18050800004 / reduction-stunting-so-focusgovernment. html.

6. (2018). "Pusdatin: Situation of Short Toddler (Stunting) in Indonesia." Indonesian Ministry of Health 1: 2.

7. Kurnia, TitonSlamet (2007), , Right to Optimal Health Degrees as Human 


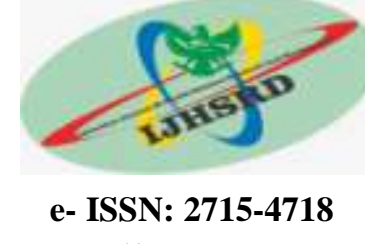

Rights in Indonesia. Bandung: PT.Alumni.

8. Mahmud Marzuki, Peter (2016). Legal Research. Revision. Jakarta: KencanaPranada Media Group.

9. Mayasari, Diana, Reni Indriyani (2018). "Stunting, Risk Factors and Prevention of Stunting, Risk Factors and Prevention" 5: 540-545. Ikkom Division, Faculty of Medicine, University of Lampung, PoltekkesKemenkesTanjungkarang, and Bandar Lampung.

10. Mugianti, Sri; Mulyadi, Arif; Khoirul, Agus; Lukluin, Zian, 2018. "Factors Causing Stunting Children Age 25-60 Months in Sukorejo District, Blitar City 1." Ners, Journal of Midwifery, Volume 5: 268-278. El Muhtsj, Majda. Dimensions of Human Rights (Describing Economic, Social and Cultural Rights). Jakarta: PT. RajawaliPers, 2008.

11. Mustafa (2015). Stunting Problems and Interventions to Prevent Stunting (A Literature Review) "2, no. 5.

12. Neta, Yulia, 2013. Community Participation in Upholding of Human Rights in Democratic Countries. Monograph.

13. Presidential Regulation Number 42 of 2013 which regulates the Implementation of the National Movement for the Acceleration of Nutrition Improvement.

14. Regulation of the Minister of Health Number 39 of 2016 concerning Guidelines for Implementing a Healthy Indonesia Program with a Family Approach

15. Pritasari, Kirana, 2019. "Efforts to Accelerate Stunting Reduction: 2018 Implementation Evaluation \& 2019 Action Plan." Bogor: Indonesian Ministry of Health.

16. Republika. WHO: 7.8 Million Toddlers in Indonesia are Stunting. Jakarta,
2018. https:

$\mathrm{m}$. republika.co.id/amp/p30s85396 S,

17. Almatseir, 2011. Basic Principles of Nutrition. Jakarta: PT. GramediaPustakaUtama.

18. Satriawan, ELan (2018). National Strategy for the Acceleration of Stunting Prevention 2018-2024. Jakarta: National Team for the Acceleration of Poverty Reduction (TNP2K).

19. Sugiyanto, S., Sumarlan, S., \& Hadi, A. J. (2020). Analysis of Balanced Nutrition Program Implementation Against Stunting in Toddlers. Unnes Journal of Public Health, 9(2), 148159.

https://doi.org/10.15294/ujph.v0i0.341 41

20. Law of the Republic of Indonesia Number 39 of 1999 concerning Human Rights (State Gazette of the Republic of Indonesia of 1999 Number 165, Supplement to the State Gazette of the Republic of Indonesia Number 3886).

21. Law of the Republic of Indonesia Number 36 of 2009 concerning Health (State Gazette of the Republic of Indonesia of 2009 Number 144, Supplement to the State Gazette of the Republic of Indonesia Number 5063).

22. Law of the Republic of Indonesia Number 23 of 2002 concerning Child Protection (State Gazette of the Republic of Indonesia of 2002 Number 109, Supplement to the State Gazette of the Republic of Indonesia Number 4235).

23. Law of the Republic of Indonesia Number 18 of 2012 concerning Food (State Gazette of the Republic of Indonesia of 2012 Number 227, Supplement to State Gazette of the Republic of Indonesia Number 5360). 